\title{
Perbedaan Pengetahuan dan Sikap Ibu yang Mendapat Penyuluhan Menggunakan Media Aplikasi Android dan yang Mendapat Penyuluhan Menggunakan Booklet tentang Senam Hamil
}

\author{
Tumiur Sormin ${ }^{1}$, Anita Puri ${ }^{2}$ \\ Jurusan Keperawatan, Politeknik Kesehatan Tanjung Karang, Indonesia \\ Email: tumiursormin@yahoo.com
}

\begin{abstract}
The Difference of Knowledge And Attitude Between Pregnant Women who Get Counseling by Android Application and Pregnancy Gymnastics Booklet. The pregnancy gymnastics is useful to decrease the difficulties of normal childbirth for mothers, which means the mortalities will be decreased. The pre-survey in Negara RatuVillage, Natar District results in 6 from 10 pregnant women $(60 \%)$ who don't know what the pregnancy gymnastics use to be, and $100 \%$ never do. Lack of knowledge and attitude are the reason pregnant women never do the pregnancy gymnastics. The research goals are knowing the difference between knowledge and attitude of pregnant women who get counseling by android applications and who get from the pregnancy gymnastic booklet in District Natar, South Lampung. This research is a Quasi Experiment type with a pre-test post-test control group design. With 129 population, 2nd and 3rd trimester and 90 samples obtained by probability sampling, divided into 3rd groups, 30th respondents are android application users, 30th respondents used booklet and 30th is controller respondent. Wilcoxon test result: the knowledge of pregnant women before counsel by android average is 10,57, after counsel is 15,67 , and p-value $=0,000$; the attitude of pregnant women before getting counsel average is 46,27 after counsel is 45,03 , and $p$-value $=0,56$. The knowledge before counsel by booklet average is 12,36 , after counsel is 15,33 , and $p$-value $=0,000$; the attitude before counsel average is 46,50, and after counsel is 48,63, and p-value=0,08. Result test by MannWhitney obtained: the difference of average between pregnant women who get knowledge counsel by android application, and of the booklet is 2,13 and $\mathrm{p}$-value $=0,68$; the difference average attitude is 0,89 and $p$-value $=0,563$. The conclusions are no difference between knowledge and attitude the pregnant women who get counsel by android applications and booklets.
\end{abstract}

Keywords: Android application, Attitude, Booklet, Counseling, Knowledge

\begin{abstract}
Abstrak: Perbedaan Pengetahuan dan Sikap Ibu yang Mendapat Penyuluhan Menggunakan Media Aplikasi Android dan yang Mendapat Penyuluhan Menggunakan Booklet Tentang Senam Hamil. Senam hamil bertujuan meminimalkan kesulitan ibu saat menjalani persalinan normal, sehingga angka kematian ibu dapat diturunkan. Hasil pre-survey di Desa Negara Ratu Kecamatan Natar, 6 orang (60\%) dari 10 ibu hamil tidak tahu manfaat senam hamil dan $100 \%$ tidak pernah melakukan. Kurangnya pengetahuandan sikap dapat menjadi penyebab sehingga ibu tidak melakukan senam hamil. Penelitian bertujuan mengetahui perbedaan pengetahuan dan sikap ibu yang mendapat penyuluhan menggunakan aplikasi android dan menggunakan booklet tentang senam hamildi Kecamatan Natar Lampung Selatan. Jenis penelitian quasi experiment dengan pre-test post-test control group design. Populasi 129 orang ibu hamil trimester II dan III dan sampel 90 orang diperolehdengan probability sampling, dibagi 3 kelompok, 30 responden menggunakan aplikasi android, 30 responden menggunakan booklet dan 30 responden kontrol. Hasil uji Wilcoxon: rata-rata pengetahuan ibu sebelum penyuluhan menggunakan aplikasi android 10,57, setelah penyuluhan 15,67, dan $p$-value $=0,000$; rata-rara sikap ibu sebelum penyuluhan 46,27 , setelah penyuluhan 45,03, dan $p$-value $=0,56$. Rata-rata pengetahuan ibu sebelum penyuluhan menggunakan booklet 12,36 , setelah penyuluhan 15,33 , dan $p$-value $=0,000$; rata-rata sikap ibu sebelum penyuluhan 46,50 , setelah penyuluhan 48,63 , dan $p$ value $=0,08$. Hasil uji Mann-Whitney, diperoleh perbedaan rata rata pengetahuan ibu yang mendapat penyuluhan menggunakan aplikasi android dengan yang mendapat penyuluhan menggunakan booklet adalah 2,13 dan $p$-value $=0,68$; perbedaan rata rata sikap ibu 0,89 dan $p$ value $=0,563$. Tidak perbedaan pengetahuan dan sikap ibu yang mendapat penyuluhan menggunakan media aplikasi android dan yang mendapat penyuluhan menggunakan booklet.
\end{abstract}

Kata kunci: Aplikasi android, Sikap, Booklet, Penyuluhan, Pengetahuan 


\section{PENDAHULUAN}

Angka Kematian Ibu (AKI) merupakan salah satu indikator yang peka menggambarkan kesejahteraan masyarakat di suatu negara, AKI di dunia 289.000 jiwa, hampir $67 \%$ kematian maternal karena penyebab langsung perdarahan $(25 \%)$, infeksi (15\%), eklamsia (12\%), abortus yang tidak aman (13\%), partus macet (8\%)(Irawan, 2015). Laporan Dinkes Provinsi Lampung 2015, sebanyak 149 orang ibu yang meninggal di tahun 2015, dengan penyebab perdarahan $46(30,8 \%)$, HDK $35 \quad(23,5 \%)$, infeksi 7 (4,7\%), penyakit jantung $10(6,7 \%)$, stroke (3,2\%), DM dan lainnya 48 (32,2\%).

Menurut WHO salah satu intervensi dalam upaya safe motherhood adalah kunjungan ANC, memastikan, bahwa setiap wanita dapat melalui kehamilan dan persalinannya dengan aman, menghasilkan bayi yang sehat, serta mempunyai akses mengenai informasi pelayanan kesehatan, salah satu kegiatan yang dapat dilakukan adalah kelas ibu (Kemenkes RI, 2014). Salah satu kegiatan kelas ibu adalah senam hamil di akhir kegiatannya, dimana senam hamil dapat menurunkan kejadian fetal distress, meminimalkan kesulitan saat menjalani persalinan normal (Clapp dan Artal dalam Widyawati, 2013). Hasil wawancara kepada bidan koordinator posyandu Puskesmas Natar, diketahui bahwa yang rutin mengikuti kelas ibu hanya 5-6 orang saja. Hasil pre-survey di Desa Negara Ratu Kecamatan Natar, 6 orang $(60 \%)$ dari 10 ibu hamil tidak tahu manfaat senam hamil dan 100\% tidak pernah melakukan.

Penyuluhan kesehatan identik dengan pendidikan kesehatan, berorientasi kepada perubahan pengetahuan, sikap dan perilaku di bidang kesehatan. Menurut Budiman, 2013, pengetahuan dapat dipengaruhi informasi dan sikap dapat dipengaruhi media massa (Azwar, 2007).

Penelitian Utami (2016) bahwa setelah dilakukan penyuluhan menggunakan aplikasi mobile berbasis android, meningkatkan pengetahuan mahasiswa sebesar $25,87 \%$ tentang cara penularan, $17,48 \%$ tentang cara pencegahan dan $25,17 \%$ tentang fakta HIV/AIDS. Penelitian Lathifa (2014) tentang perbandingan antara tingkat pengetahuan ibu hamil sebelum dan sesudah mengikuti program kelas ibu di wilayah Bangsri Jepara, didapatkan pengaruh signifikan dengan nilai $p$-value $=0,001<\alpha(0.05)$. Media informasi saat ini berkembang pesat, memberikan kemudahan bagi yang memerlukan. Informasiinformasi yang dibutuhkan semakin mudah diakses menggunakan komputer/perangkat lain sebagai media belajar. Pengembangan aplikasi android didukung oleh Google yang menyediakan software untuk mengembangkan aplikasi. Melalui aplikasi ini memungkinkan bagi ibu-ibu hamil yang kesulitan mengikuti senam hamil di kelas ibu dan dapat melakukannya dirumah sendiri tanpa harus rutin tatap muka di kelas ibu.

Berdasar latar belakang di atas, dilakukan penelitian perbedaan pengetahuan dan sikap ibu yang mendapat penyuluhan menggunakan media aplikasi android dan yang mendapat penyuluhan menggunakan media booklet tentang senam hamil di wilayah kerja Puskesmas Natar Kabupaten Lampung Selatan Provinsi Lampung Tahun 2018. Penelitian dilakukan kepada ibu hamil trimester II dan III di Wilayah Kerja Puskesmas Natar Lampung Selatan.

Penelitian bertujuan mengetahui rata-rata pengetahuan, rata-rata sikap ibu sebelum dan sesudah penyuluhan menggunakan media aplikasi android tentang senam hamil; rataratapengetahuan, rata-rata sikap sebelum dan sesudah mendapat penyuluhan menggunakan booklet tentang senam hamil; perbedaan rata rata pengetahuan, rata-rata sikap ibu yang mendapat penyuluhan menggunakan media aplikasi android dan yang mendapat penyuluhan menggunakan booklet tentang senam hamil.

\section{METODE}

Jenis penelitian ini adalah penelitian eksperimen semu (quasi exsperimental) dengan rancangan pre-test dan post-test kelompok kontrol (pre-test post-test control group design). Sampel penelitian sebanyak 90 orang dari 129 ibu hamil trimester II dan III. Teknik sampel menggunakan accidental sampling. Sampel dibagi tiga kelompok, 30 responden mendapat perlakuan penyuluhan menggunakan aplikasi android, 30 responden mendapat perlakuan penyuluhan menggunakan booklet dan 30 responden sebagai kontrol tanpa perlakuan. Kepada sampel penelitian ekperimen dan sampel kontrol, dilakukan pengukuran pengetahuan dan sikap sebelum dan sesudah penyuluhan.

Teknik analisis data dengan univariat untuk menggambarkan distribusi frekuensi dan persentase dari variabel pengetahuan baik/ kurang dan sikap positif/negatif. Uji Wilcoxon digunakan untuk mengetahui pengaruh penyuluhan terhadap pengetahuan dan sikap ibu tentang senam hamil. Uji Mann-Whitney digunakan untuk mengetahui selisih rata-rata atau perbedaan pengetahuan dan sikap ibu tentang 
senam hamil pada kelompok yang mendapat penyuluhan menggunakan aplikasi android dan yang menggunakan booklet.

Penelitian ini telah mendapatkan Ethical Clearance No 180/EC/KEP-TJK/VI/2018 dari Komisi Etik Penelitian Kesehatan Politeknik Kesehatan Tanjung Karang.

HASIL

Tabel 1. Ditribusi Pengetahuan dan Sikap Responden tentang Senam Hamil Sebelum dan Sesudah Penyuluhan

\begin{tabular}{lcccr}
\hline \multicolumn{1}{c}{ Variabel } & \multicolumn{1}{c}{ Sebelum } & \multicolumn{2}{c}{ Sesudah } \\
\hline Penyuluhan menggunakan aplikasi android & \\
\hline Pengetahuan: & & & & \\
- Baik & 17 & $56,70 \%$ & 23 & $76,70 \%$ \\
- Kurang & 13 & $43,30 \%$ & 7 & $23,30 \%$ \\
Sikap: & & & & \\
- Positip & 15 & $50.00 \%$ & 23 & $76,70 \%$ \\
- Negatif & 15 & $50,00 \%$ & 7 & $23,30 \%$ \\
\hline Penyuluhan menggunakan Booklet: & & \\
\hline Pengetahuan: & & & & \\
- Baik & 15 & $50.00 \%$ & 23 & $76,70 \%$ \\
- Kurang & 15 & $50,00 \%$ & 7 & $23,30 \%$ \\
Sikap: & & & & \\
- Positip & 12 & $40,00 \%$ & 19 & $63,30 \%$ \\
- Negatif & 18 & $60,00 \%$ & 11 & $36,37 \%$ \\
\hline Kelompok kontrol & & & & \\
\hline Pengetahuan: & & & & \\
- Baik & 11 & 36,70 & 14 & 46,70 \\
- Kurang & 19 & 63,30 & 16 & 53,30 \\
Sikap: & & & & \\
- Positip & 10 & $33,30 \%$ & 14 & $46,70 \%$ \\
- Negatif & 20 & $66,70 \%$ & 16 & $53,30 \%$ \\
\hline
\end{tabular}

Tabel 2. Skor Pengetahuan dan Sikap Responden Pengukuran Pertama dan Kedua tentang Senam Hamil dengan Penyuluhan Menggunakan Media Aplikasi Android dan Booklet

\begin{tabular}{|c|c|c|c|c|c|}
\hline \multirow{2}{*}{ Variabel } & \multirow{2}{*}{ Mean } & \multirow{2}{*}{ Med } & \multirow{2}{*}{$S D$} & \multicolumn{2}{|c|}{ Nilai } \\
\hline & & & & Min & $\operatorname{Max}$ \\
\hline \multicolumn{6}{|c|}{ Penyuluhan menggunakan aplikasi android } \\
\hline \multicolumn{6}{|l|}{ Pengetahuan: } \\
\hline -Skor Pertama & 10,57 & 12,00 & 3,501 & 4 & 16,00 \\
\hline -Skor Kedua & 15,67 & 15,00 & 3,356 & 10 & 21,00 \\
\hline \multicolumn{6}{|l|}{ Sikap: } \\
\hline -Skor Pertama & 46,27 & 48,00 & 7,50 & 24 & 46,27 \\
\hline -Skor Kedua & 45,03 & 51,00 & 16,1 & 0 & 60,00 \\
\hline \multicolumn{6}{|c|}{ Penyuluhan menggunakan booklet } \\
\hline \multicolumn{6}{|l|}{ Pengetahuan: } \\
\hline -Skor Pertama & 12,36 & 11,00 & 3,09 & 9 & 19,00 \\
\hline -Skor Kedua & 15,33 & 15,00 & 2,67 & 10 & 21,00 \\
\hline \multicolumn{6}{|l|}{ Sikap: } \\
\hline -Skor Pertama & 46,50 & 46,50 & 6,46 & 25 & 60,00 \\
\hline -Skor Kedua & 48,63 & 48,00 & 5,33 & 38 & 60,00 \\
\hline \multicolumn{6}{|c|}{ Kelompok Kontrol } \\
\hline \multicolumn{6}{|l|}{ Pengetahuan: } \\
\hline Skor Pertama & 12,63 & 13,00 & 2,60 & 7 & 17,00 \\
\hline Skor Kedua & 12,77 & 13,00 & 2,56 & 5 & 18,00 \\
\hline Sikap: & & & 0 & 30 & 47,87 \\
\hline Skor Kedua & $\begin{array}{l}4 /, 8 / \\
46,53\end{array}$ & 46,00 & 9,11 & 25 & 60,00 \\
\hline
\end{tabular}

Tabel 3. Distribusi Rata-Rata Pengetahuan dan Sikap Responden pada Pengukuran Pertama dan Kedua Penyuluhan tentang Senam Hamil

\begin{tabular}{|c|c|c|c|c|}
\hline Variabel & Mean & SD & p-value & $\mathbf{n}$ \\
\hline \multicolumn{5}{|c|}{ Penyuluhan menggunakan aplikasi android } \\
\hline \multicolumn{5}{|l|}{ Rata-rata pengetahuan: } \\
\hline - Pengukuran I & 10,57 & 3,501 & 0,000 & 30 \\
\hline - Pengukuran II & 15,67 & 3,356 & & \\
\hline \multicolumn{5}{|l|}{ Rata-rata sikap: } \\
\hline -Pengukuran I & 46,27 & 7,501 & 0,56 & 30 \\
\hline - Pengukuran II & 45,03 & 16,100 & & \\
\hline \multicolumn{5}{|c|}{ Penyuluhan menggunakan aplikasi booklet } \\
\hline \multicolumn{5}{|l|}{ Rata-rata pengetahuan: } \\
\hline - Pengukuran I & 12,36 & 3,095 & 0,000 & 30 \\
\hline - Pengukuran II & 15,33 & 2,670 & & \\
\hline \multicolumn{5}{|l|}{ Rata-rata sikap: } \\
\hline - Pengukuran I & 46,50 & 6,463 & 0,08 & 30 \\
\hline - Pengukuran II & 48,63 & 5,334 & & \\
\hline \multicolumn{5}{|l|}{ Kelompok kontrol } \\
\hline \multicolumn{5}{|l|}{ Rata-rata pengetahuan: } \\
\hline - Pengukuran I & 12,63 & 2,606 & 0,685 & 30 \\
\hline - Pengukuran II & 12,77 & 2,569 & & \\
\hline \multicolumn{5}{|l|}{ Rata-rata sikap: } \\
\hline - Pengukuran I & 47,87 & 6,907 & 0,31 & 30 \\
\hline - Pengukuran II & 46,53 & 9,119 & & \\
\hline
\end{tabular}

Tabel 4. Perbedaan Rata-Rata Pengetahuan dan Sikap Responden

\begin{tabular}{llcc}
\hline Jenis Kelompok & $\begin{array}{c}\text { Selisih } \\
\text { Mean }\end{array}$ & $\begin{array}{c}p \text { - } \\
\text { value }\end{array}$ & n \\
\hline $\begin{array}{l}\text { Perbedaan pengetahuan: } \\
\text {-Kelompok aplikasi android }\end{array}$ & 5,10 & 0,687 & 30 \\
-Kelompok booklet & 2,97 & & \\
-Kelompok android & 5,10 & 0,001 & 30 \\
-Kelompok kontrol & 0,14 & & \\
-Kelompok booklet & 2,97 & 0,001 & 30 \\
-Kelompok Kontrol & 0,14 & & \\
Perbedaan sikap: & & & \\
-Kelompok aplikasi android & 1,24 & 0,563 & 30 \\
-Kelompok booklet & 2,13 & & \\
-Kelompok android & 1,24 & 0,428 & 30 \\
-Kelompok kontrol & 1,34 & & \\
-Kelompok Booklet & 2,13 & 0,514 & 30 \\
-Kelompok Kontrol & 1,34 & & \\
\hline
\end{tabular}

\section{PEMBAHASAN}

Hasil penelitian yang diperoleh bahwa adanya pengaruh penyuluhan menggunakan media aplikasi android maupun booklet terhadap pengetahuan tetapi tidak berpengaruh terhadap sikap ibu hamil tentang senam hamil di wilayah kerja Puskesmas Natar. Diperoleh juga hasil yang menunjukkan bahwa tidak adanya perbedaan pengetahuan dan sikap ibu antara kelompok yang mendapat penyuluhan menggunakan media aplikasi android dan yang menggunakan booklet tentang senam hamil tersebut.

Hasil analisis univariat diketahui bahwa dengan menggunakan media aplikasi android diperoleh rata-rata pengetahuan ibu pada 
pengukuran pertama (sebelum penyuluhan) 10,57, standar deviasi (SD) 3,501; pengukuran kedua (setelah penyuluhan), 15,67, SD 3,35, dan nilai $p$-value $=0,000$, yang artinya bahwa pada alpha $5 \%$ ada perbedaan signifikan rata-rata pengetahuan sebelum dan sesudah penyuluhan. Hasil penelitian juga menunjukkan bahwa sesudah penyuluhan menggunakan media aplikasi android, jumlah ibu yang pengetahuan baik bertambah, yakni dari 17 orang $(56,70 \%)$ dari 30 orang, bertambah menjadi 23 orang $(76,70 \%)$. Demikian juga penyuluhan dengan menggunakan booklet, diperoleh rata-rata pengetahuan ibu pada pengukuran pertama 12,36, SD 3,09 dan pada pengukuran kedua 15,33 , SD 2,67 dengan nilai $p$-value $=0,000$. Berarti pada alpha 5\%, ada perbedaan yang signifikan rata-rata pengetahuan sebelum dan sesudah penyuluhan menggunakan media booklet. Hasil penelitian juga menunjukkan bahwa sesudah penyuluhan menggunakan booklet, terdapat penambahan jumlah ibu yang pengetahuan baik, yakni dari 18 orang $(60 \%)$, menjadi 20 orang $(66,70 \%)$ dari 30 orang ibu. Meskipun pertambahan jumlah ini tidak sebesar pada penyuluhan yang menggunakan aplikasi android, tetapi tetap ada hasil yang menunjukkan bahwa dengan booklet pun terjadi perubahan jumlah ibu dengan pengetahuan baik tentang senam hamil.

Istiyanto (2013), menjelaskan faktor penyebab popularitas aplikasi android, yaitu faktor kecepatan dimana efisiensi aplikasi dalam memberikan data secara tepat sesuai dengan keinginan user. Aplikasi mobile dibuat sederhana untuk kebutuhan tertentu sehingga pengguna dapat dengan mudah dan cepat mengakses data yang ia butuhkan. Hasil penelitian yang didapatkan, dimana dengan media aplikasi android dapat meningkatkan jumlah ibu hamil yang pengetahuan baik tentang senam hamil. Keadaan ini sesuai dengan penelitian Utami, 2016 tentang pengaruh penyuluhan HIV/AIDS dengan menggunakan media aplikasi android kepada 143 mahasiswa di Jakarta, dimana. meningkat pengetahuan mahasiswa tentang cara penularan HIV/AIDS sebesar 25,87\%.

Sebagaimana dikatakan oleh Arsyad (2002), perkembangan teknologi media informasi saat ini, berkembang pesat dan memberikan kemudahan bagi yang memerlukan. Informasiinformasi yang dibutuhkan saat ini semakin mudah diakses dengan menggunakan komputer maupun perangkat lain sebagai media belajar. Pembuatan media pembelajaran juga lebih mudah, berbagai software tersedia untuk membuatnya. Dukungan software inilah yang dapat membuat media pembelajaran semakin menarik dan lebih mudah diproduksi. Pengembang media juga membuat berbagai penyesuaian sesuai dengan keadaan pengguna berdasarkan pendidikan dan umur, serta membuat pengguna lebih leluasa menjalankan aktifitas mobile.

Menurut Notoatmodjo (2005), bahwa media penyuluhan adalah semua sarana atau upaya menampilkan pesan/informasi yang ingin disampaikan komunikator, baik media cetak, elektronika dan media luar ruang sehingga sasaran meningkat pengetahuannya yang akhirnya diharapkan dapat berubah prilakunya ke arah positif. Media pendidikan berdasarkan fungsinya, termasuk adalah booklet, leaflet, flyer, flip chart, rubrik/majalah, poster, dan foto. Oleh karena itu, booklet senam hamil pada penelitian ini juga merupakan salah satu media pembelajaran yang dapat dibaca secara berulangulang sehingga memungkinkan dapat meningkatkan pengetahuan ibu hamil tentang senam hamil.

Hasil penelitian yang diperoleh bahwa rata-rata sikap ibu hamil yang mendapat penyuluhan menggunakan media aplikasi android pengukuran pertama (sebelum penyuluhan) 46,27 , SD 7,50 dan rata-rata sikap pengukuran kedua (setelah penyuluhan) 45,03 dengan SD 16,1 , nilai $p$-value $=0,56$, artinya pada alpha $5 \%$ tidak ada perbedaan yang signifikan rata-rata sikap sebelum dan sesudah penyuluhan. Sebelum dilakukan penyuluhan, ibu hamil yang memiliki sikap positif ada 15 orang (50\%) dan sesudah penyuluhan, bertambah menjadi 23 orang $(76,70 \%)$, tetapi hasil uji statistik menunjukkan tidak adanya perbedaan yang signifikan rata-rata sikap ibu sebelum dan sesudah penyuluhan. Jadi, meskipun secara jumlah adanya penambahan, tetapi tidak ada perbedaan yang signifikan sebelum dan sesudah penyuluhan menggunakan media aplikasi android.

Azwar (2007), mengatakan bahwa sikap yang timbul tidak saja ditentukanoleh keadaan objek yang sedang dihadapi tetapi juga kaitannya dengan pengalaman masa lalu, situasi sekarang, dan harapan masa yang akan datang. Bila diamati lebih lanjut tentang jawaban-jawaban ibu tentang sikap terhadap senam hamil, diantaranya mereka hanya 8 orang ibu (28\%) yang menyatakan setuju dengan perlunya lebih mengutamakan senam hamil dari pekerjaan rumah, 9 orang ibu (30\%) menyatakan setuju bahwa senam hamil perlu diikuti ibu hamil supaya ibu percaya diri menghadapi persalinannya. Ibu menyatakan setuju tentang senam hamil perlu dilakukan 
secara baik dan teratur supaya siap menghadapi persalinan normal hanya 6 orang ibu (20\%).

Responden penelitian yang mendapat penyuluhan dengan media aplikasi android ini bervariasi dalam kehamilannya, 16 orang $(53 \%)$ adalah ibu hamil anak ke-2 dan 6 orang $(20 \%)$ anak ke-3, dan 3 orang (10\%) kehamilan ke-4. Mereka mengatakan bahwa belum pernah mengikuti senam hamil. Mereka menganggap senam hamil tidak harus dilakukan, tanpa senam persalinan sebelumnya lancar saja tanpa masalah. Keadaan inilah yang dikatakan oleh Azwar (2007), bahwa sikap yang timbul tidak saja ditentukanoleh keadaan objek yang sedang dihadapi tetapi juga kaitannya dengan pengalaman masa lalu.

Rata-rata sikap ibu yang mendapat penyuluhan menggunakan media booklet pengukuran pertama (sebelum penyuluhan) 46,50, SD 6,46 dan pengukuran kedua (setelah penyuluhan), 48,63, SD 5,34, dan nilai $p$ value $=0,08$, artinya pada alpha $5 \%$ tidak ada perbedaan rata-rata sikap sebelum dan sesudah penyuluhan menggunakan booklet. Hasil penelitian juga menunjukkan bahwa sesudah penyuluhan dengan menggunakan booklet, ada 1 orang $(0,03 \%)$ sajapenambahanibu hamil yang sikap positif sehingga dari 18 orang (60\%) menjadi 19 orang $(63,30 \%)$.

Sebagaimana penyuluhan senam hamil dengan media aplikasi android, yang menunjukkan tidak adanya perbedaan rata-rata sikap yang signifikan sebelum dan sesudah penyuluhan, demikian juga pada penyuluhan dengan menggunakan media booklet. Jadi meskipun secara jumlah adanya penambahan sikap ibu yang positif setelah penyuluhan tetapi tidak ada perbedaan yang signifikan rata-rata sikap ibu sebelum dan sesudah penyuluhan.

Sebagaimana dikatakan LaPierre (dalam Azwar, 2007) bahwa sikap adalah sebagai suatu pola perilaku, tendensi, atau kesiapan antisipatif, predisposisi untuk menyesuaikan diri dalam situasi sosial. Oleh Azwar (2007), bahwa tidak adanya pengalaman seseorang dengan suatu objek psikologis, cenderung membentuk sikap negatif terhadap objek tersebut. Dikatakan juga bahwa pengaruh orang lain yang penting: pada umumnya, individu cenderung untuk memiliki sikap yang konformis/searah dengan sikap orang yang dianggapnya penting. Sebanyak 12 orang (40\%) responden penelitian ini adalah kehamilan ke-2 dan 4 orang ibu (12\%) anak ke-3, dan 4 orang (13\%) kehamilan ke-4. Sebanyak 8 orang (26\%) ibu mengatakan bahwa belum begitu paham tentang senam hamil dan pada kehamilan sebelumnya tidak mengalami masalah pada persalinanya, persalinan sebelumnya lancarlancar saja Sebagaimana dikatakan oleh Azwar (2007) bahwa sikap yang timbul tidak saja ditentukan oleh keadaan objek yang sedang dihadapi tetapi juga kaitannya dengan pengalaman masa lalu. Oleh karena itu senam hamil tidak menjadi prioritas dalam kehamilannya.

Perbedaan rata rata pengetahuan ibu yang mendapat penyuluhan menggunakan media aplikasi android dan yang mendapat penyuluhan menggunakan booklet tentang senam hamil adalah 2,13, p-value $=0,687$, artinya pada alpha $5 \%$ tidak ada perbedaan rata-rata pengetahuan ibu yang mendapat penyuluhan menggunakan media aplikasi android danyang mendapat penyuluhan menggunakan booklet tentang senam hamil. Perbedaan rata-rata pengetahuan responden yang mendapat penyuluhan menggunakan media aplikasi android dengan ibu kelompok kontrol adalah 4,96, $p$-value $=0,001$, berarti pada alpha $5 \%$, ada perbedaan rata-rata pengetahuan pada penyuluhan menggunakan media aplikasi android dengan kelompok kontrol. Rata-rata pengetahuan responden tentang senam hamil pada penyuluhan menggunakan booklet dengan kelompok kontrol adalah 2,83, $p$-value $=0,001$, berarti pada alpha $5 \%$ ada perbedaan rata-rata pengetahuan pada penyuluhan menggunakan booklet dengan kelompok kontrol. Jadi, baik media aplikasi android maupun booklet memberi perubahan rata-rata yang signifikan kepada pengetahuan ibu hamil tentang senam hamil.

Menurut Notoatmodjo (2003), bahwa di dalam penyuluhan ada kegiatan belajar yang harus disesuaikan dengan latar belakangnya peserta, pengaruh timbal balik antara berbagai faktor, seperti subjek belajar, pengajar/fasilitator, metode, alat bantu dan materi belajar. Lebih lanjut oleh J. Guilbert (dalam Notoatmodjo, 2003), faktor materi, lingkungan, instrumental dan individual subjek belajar mempengaruhi belajar peserta pembelajaran. Hasil penelitian menunjukkan bahwa responden penelitian yang mendapat penyuluhan menggunakan media aplikasi android, terdiri dari 13 orang (45\%) latar pendidikan SMP ke bawah dan bekerja sebagai ibu rumah tangga sebanyak 21 orang (70\%). Sebanyak 24 orang ibu (80\%) menggunakan android yang dimilikinya untuk kebutuhan whats app (WA) kepada keluarga/saudara, untuk menelpon saja dan belum begitu paham menggunakan fitur-fitur lainnya yang tersedia di aplikasi android. Sedangkan responden penelitian yang mendapat penyuluhan menggunakan booklet, terdiri dari 20 orang (65\%) latar pendidikan SMP kebawah, bekerja sebagai ibu 
rumah tangga 15 orang ibu (50\%) dan 5 orang ibu (16\%) bekerja sebagai buruh. Sebanyak 25 orang ibu $(83 \%)$ ibu mengatakan selalu sibuk dengan pekerjaan rumah tangga dan mengasuh anak, belum pernah mendapat informasi/penyuluhan tentang senam hamil sebanyak 12 orang ibu $(40 \%)$.

Media atau alat peraga dalam promosi kesehatan dapat diartikan sebagai alat bantu untuk promosi kesehatan yang dapat dilihat, didengar, diraba, dirasa atau dicium, untuk memperlancar komunikasi dan penyebarluasan informasi. Sehingga tidak ada satu media pun yang paling baik, akan tetapi adalah mengkombinasi beberapa media atau disesuaikan dengan latar belakang sasaran/peserta didik. Penyajian pesan yang tepat dan bervariasi dapat mengatasi sikap pasif anak didik, memberikan perangsang belajar yang sama, menyamakan pengalaman dan menimbulkan persepsi yang sama (Sadiman, dkk., 2011). Tidak adanya perbedaan rata-rata pengetahuan ibu yang yang mendapat penyuluhan menggunakan aplikasi android dan booklet, berbeda ketika dibandingkan dengan kelompok kontrol. Juga terkait latar belakang pendidikan, pengalaman dan pekerjaan ibu hamil yang bervariasi di wilayah kerja Puskesmas Natar, kemungkinan hasil perubahan rata-rata pengetahuan akan berbeda jikasaja melakukan penyuluhan selanjutnya dengan mengkombinasi media aplikasi android dan booklet. Bahkan, jika memungkinkan menambah media-media lainnya untuk menyesuaikan dengan kemampuan ibu-ibu menggunakan media tersebut mempelajari tentang senam hamil.

Rata-rata sikap ibu yang mendapat penyuluhan menggunakan media aplikasi android dan booklet adalah 0,89, $p$-value $=0,563$, artinya pada alpha $5 \%$ tidak ada perbedaan ratarata sikap ibu yang mendapat penyuluhan menggunakan media aplikasi android dan booklet tentang senam hamil. Perbedaan rata-rata sikap ibu tentang senam hamil pada ibu yang mendapat penyuluhan menggunakan media aplikasi android dengan kelompok kontrol 0,10, pvalue $=0,42$, artinya bahwa pada alpha $5 \%$ tidak ada perbedaan rata-rata sikap ibu pada penyuluhan menggunakan media aplikasi android dan kelompok kontrol. Rata-rata sikap ibu yang mendapat penyuluhan menggunakan booklet dengan kelompok kontrol, adalah 0,79, $p$ value $=0,514$, berarti pada alpha $5 \%$ tidak ada perbedaan sikap pada penyuluhan menggunakan booklet dan kelompok kontrol. Sehingga, baik media aplikasi android maupun booklet tidak memberi perubahan signifikan kepada sikap ibu tentang senam hamil.

Menurut Notoatmodjo (2005) bahwa media atau alat peraga dalam promosi kesehatan adalah yang dapat dilihat, didengar, diraba, dirasa atau dicium untuk memperlancar komunikasi dan gagasan yang terkandung di dalamnya dan harus dapat diterima oleh sasaran. Lebih lanjut dikatakan bahwa untuk merubah sikap dapat dilakukan dengan metode diskusi kelompok, tanya jawab, role playing, film/video, tape recorder dan simulasi. J. Guilbert (dalam Notoatmodjo, 2003), mengatakan bahwa faktor materi, lingkungan, instrumental dan individual subjek belajar mempengaruhi belajar peserta pembelajaran.

Pada penelitian ini, diterapkan adalah menggunakan media aplikasi android dan booklet yakni sebatas media yang dapat dilihat/dibaca, metode digunakan dengan diskusi, tanya jawab. Oleh Notoatmodjo (2005) dikatakan bahwa upaya merubah sikap dapat dengan menerapkan media kombinasi yang dapat dilihat, didengar, diraba, dirasa, dicium untuk memperlancar komunikasi dan dapat diterima oleh sasaran. Disamping itu juga perlu mengkombinasi metode yang seperti diskusi kelompok, tanya jawab, roleplaying, film/video, tape recorder dan simulasi.

Sebagaimana pendapat Sadiman, 2011, bahwa tidak ada satu media pun yang paling baik, akan tetapi adalah mengkombinasi beberapa media atau disesuaikan dengan latar belakang sasaran/peserta didik. Penyajian pesan yang tidak terlalu bersifat verbalistis, mengatasi keterbatasan ruang, waktu dan daya indera, penggunaan media pembelajaran yang tepat dan bervariasi dapat mengatasi sikap pasif sasaran pembelajaran, memberikan perangsang belajar yang sama, menyamakan pengalaman dan menimbulkan persepsi yang sama.

\section{SIMPULAN}

Ada perbedaan rata-rata pengetahuan ibu yang mendapat penyuluhan menggunakan media aplikasi android maupun menggunakan booklet, sebelum dan setelah penyuluhan. Tidak ada perbedaan sikap ibu yang mendapat penyuluhan menggunakan media aplikasi android, sebelum dan setelah penyuluhan. Tidak ada perbedaan pengetahuan ibu yang mendapat penyuluhan menggunakan media aplikasi android dan yang menggunakan booklet. Tidak ada perbedaan sikap tentang senam hamil pada ibu yang mendapat penyuluhan menggunakan media 
aplikasi android dengan yang mendapat penyuluhan menggunakan booklet.

\section{DAFTAR PUSTAKA}

Arsyad, A. (2002). Media Pembelajaran. Jakarta: Raja Grafindo Persada.

Azwar, Saifuddin. (2007). Sikap Manusia Teori dan Pengukurannya. Yogyakarta: Pustaka Pelajar.

Dinkes Lampung Selatan. (2016). Profil Kesehatan, Dinkes Lampung Selatan. Provinsi Lampung Selatan.

Istiyanto, J. Eko. (2013). Pemograman Smartphone menggunakan SDK Android dan Hacking Android. Yogyakarta: Graha Ilmu.

Kemenkes RI. (2014). Senam Hamil: Dilakukan Setiap Hari Untuk Memperlancar Proses Persalinan. Jakarta.

Lathifa. (2014). Perbandingan Antara Tingkat Pengetahuan Ibu Hamil Sebelum dan Sesudah Mengikuti Program Kelas Ibu di Wilayah Bangsri Jepara. [Skripsi]. Surakarta: Universitas Muhammadiyah Surakarta.
Notoatmodjo, Soekidjo. (2005). Promosi Kesehatan Teori dan Aplikasi. Jakarta: PT. Rineka Cipta.

Notoatmodjo, Soekidjo. (2003). Pendidikan dan Ilmu Perilaku Kesehatan. Jakarta: PT. Rineka Cipta.

Sadiman,Arif, S. dkk. (2011). Media Pendidikan, Pengertian, Pengembangan, dan Pemanfaatannya. Jakarta: PT. Raja Grafindo Persada.

Utami, S. Puji. (2016). Peningkatan Pengetahuan HIV/AIDS Dengan Memanfaatkan Aplikasi Mobile Android. Jurnal penelitian dan Pengabdian ETHOS, Vol.4 No.1, Januari 2016 https://ejournal.unisba.ac.id/index.php/etho s/index.

Widyawati \& Fariani Syahrul. (2013). Pengaruh Senam Hamil Terhadap Proses Persalinan dan Status Kesehatan Neonatus. Surabaya: Universitas Airlangga. 